\title{
Non-invasive ventilation in the treatment of severe polymicrobial community-acquired pneumonia
}

\author{
Enrico Cinque, ${ }^{1}$ Ines Maria Grazia Piroddi, ${ }^{2}$ Cornelius Barlascini, ${ }^{3}$ Alessandro Perazzo, ${ }^{2}$ Antonello Nicolini ${ }^{2}$ \\ ${ }^{1}$ Intensive Care Unit, Hospital of Lavagna, Lavagna (GE); ${ }^{2}$ Respiratory Diseases Unit, Hospital of Sestri Levante, Sestri Levante \\ (GE); ${ }^{3}$ Hygiene and Health Medicine Unit, Hospital of Sestri Levante, Sestri Levante (GE), Italy
}

\begin{abstract}
Polymicrobial pneumonia may be caused by the combination of respiratory viruses, bacteria and fungi in a host. Colonization by Streptococcus pneumoniae was associated with increased risk of Intensive Care Unit admission or death in the setting of influenza infection, whereas the colonization by methicillin sensible Staphylococcus aureus co-infection was associated with severe disease and death in adults and children. The principal association of pathogens in community-acquired pneumonia (CAP) is bacteria and viral co-infection, and accounts approximately for 39\% of microbiological diagnosed cases of CAP. The differential clinical diagnosis between a viral and a bacterial CAP is not easy: no clinical signs or radiological findings help the clinician to suspect to the diagnosis. Patients with polymicrobial infections are more likely to have underlying medical conditions and have more severe outcome. Severe respiratory failure and need of mechanical ventilation occur in several cases. Non invasive ventilation (NIV) use aims to avoid invasive mechanical ventilation. NIV treatment is controversial owing to high reported treatment failure. In this case series we report three cases of severe polymicrobial CAP: all of them required NIV with a good outcome.
\end{abstract}

\section{Introduction}

Community-acquired pneumonia (CAP) is the leading cause of death from infectious diseases. Bacterial pneumonia in association with virus infection has been considered an important factor leading to poor patient outcomes. ${ }^{1-3}$

The role of bacterial co-infection in complicating the clinical course of virus-associated pneumonia is poorly known, although it is often considered a cause of excess morbidity and mortality in community-acquired pneumonia. ${ }^{1,4-7}$

Microbial synergies among bacteria, fungi, and

Correspondence: Antonello Nicolini, Respiratory Diseases Unit, Hospital of Sestri Levante, via Terzi 43, 16039 Sestri Levante (GE), Italy.

Tel.: +39.018541031 - Fax: +39.0185329935.

E-mail: antonellonicolini@gmail.com

Key words: Polymicrobial-community-acquired pneumonia; severe respiratory failure; non-invasive ventilation.

Received for publication: 22 November 2015.

Revision received: 2 May 2016

Accepted for publication: 1 June 2016.

This work is licensed under a Creative Commons Attribution NonCommercial 4.0 License (CC BY-NC 4.0).

(C) Copyright E. Cinque et al., 2017

Licensee PAGEPress, Italy

Italian Journal of Medicine 2017; 11:57-60

doi:10.4081/itjm.2017.675 viruses are further described. ${ }^{8}$ Bilateral pneumonia is a risk factor for the need for respiratory support and death. Development of respiratory complications confers greater risk of morbidity. Polymicrobial-community-acquired pneumonia are more frequently associated with more severe course compared with monomicrobial pneumonia cases. ${ }^{3,8}$

Currently, the treatment of severe-CAP consists of antibiotic therapy and ventilator support. The use of invasive ventilation causes several complications, such as the admission to Intensive Care Unit (ICU): for this reason, non-invasive ventilation (NIV) has been used for acute respiratory failure to avoid endotracheal intubation. However, few studies have assessed the usefulness of NIV in pneumonia patients. The use of NIV in patients with pneumonia is controversial because of a greater variability in failure rates than those observed in other diagnoses. ${ }^{9,10,11}$ On this regard, we report three cases of severe polymicrobial CAP: all of them required NIV with good outcome. Patients gave their consent to publish material related to them.

\section{Case Series}

\section{Case \#1}

A 57-year-old man, homeless was taken to the Emergency Department (ED) after a history of three day of fever $\left(39^{\circ} \mathrm{C}\right)$ cough and purulent expectoration. He presented alcohol abuse, and untreated chronic obstructive pulmonary diseases. Later he was transferred to Respiratory Sub-ICU. At admission to Respiratory Sub-ICU, vital signs were: breathing frequency 38 m', 
cardiac frequency 124 beats m' arterial pressure 95/55 $\mathrm{mmHg}$. Laboratory data revealed marked elevation of inflammation and infectious parameters (leukocytes $22.30 \times 10^{9} / \mathrm{L}$, with neutrophils $85 \%$, lymphocytes $9 \%$, C-reactive protein $20.06 \mathrm{mg} / \mathrm{dL}$, Pro-calcitonin 2.5 $\mathrm{ng} / \mathrm{mL}$ sodium $132 \mathrm{mEq} / \mathrm{L}$, potassium $3.3 \mathrm{mEq} / \mathrm{L}$ ). Arterial blood gas analysis showed hypoxemic respiratory failure $\mathrm{paO}_{2} 45 \mathrm{mmHg}, \mathrm{paCO}_{2} 32 \mathrm{mmHg}, \mathrm{pH}$ 7.49, $\mathrm{paO}_{2} / \mathrm{FiO}_{2}$ ratio 214). Chest X-ray and computed tomography (CT) of the thorax (Figure 1) showed an opacity in the lower pulmonary lobe. The patient was treated with empirical therapy ceftriaxone $2 \mathrm{~g}$ per day + levofloxacin $500 \mathrm{mg}$ twice a day, and oxygen via Venturi mask $50 \%$. Over the next $6 \mathrm{~h}$ the respiratory conditions worsened as shown by the next arterial blood gas analysis (ABG) $\left(\mathrm{paO}_{2} 60, \mathrm{paCO}_{2} 42, \mathrm{pH}\right.$ $7.35, \mathrm{paO}_{2} / \mathrm{FiO}_{2}$ 120). The patient underwent non-invasive ventilation, bilevel positive airway pressure (BiPAP), inspiratory PAP $15 \mathrm{cmH}_{2} \mathrm{O}$, expiratory PAP $8 \mathrm{cmH}_{2} 0, \mathrm{FiO}_{2} 30 \%$ with prompt improvement of gas exchange $\left(\mathrm{paO}_{2} 75, \mathrm{paCO}_{2} 37, \mathrm{pH} 7.37, \mathrm{paO}_{2} / \mathrm{FiO}_{2}\right.$ 250). Urinary antigen was positive both for Legionella pneumophila and Streptococcus pneumoniae. Blood culture was positive for S. pneumoniae as well Legionella antibodies. The clinical picture progressively improved. NIV was suspended after a week; after seventeen days was observed a normalization of inflammation parameters (leukocytes $5.8 \times 10^{9} / \mathrm{L}$, C-reactive protein 0.45 ) and the patient was discharged.

\section{Case \#2}

A 63-year-old woman was admitted to ED complaining dyspnea, cough, purulent expectoration and fever $\left(39^{\circ}\right)$, polyuria, vomit and diahrrea and transferred to ICU because of severity of clinical condition. At admission to the ICU clinical picture was as follows: respiratory breathing $36 \mathrm{~m}$ ' cardiac frequency 139 beats m' arterial pressure 95/45 mmHg. Laboratory data showed: leukocytes $19.60 \times 10^{9} / \mathrm{L}$, with neutrophils $79 \%$, lymphocytes $12 \%$, C-reactive protein $18.12 \mathrm{mg} / \mathrm{dL}$, pro-calcitonin $2.0 \mathrm{ng} / \mathrm{mL}$, creatinine $1.40 \mathrm{mg} / \mathrm{dL}$ [normal values (n.v.) $0.55-1.2 \mathrm{mg} / \mathrm{dL}$ ] sodium $144 \mathrm{mEq} / \mathrm{L}$, potassium $3.4 \mathrm{mEq} / \mathrm{L}$. Arterial blood gas analysis showed hypoxemic respiratory failure $\left(\mathrm{paO}_{2} 36 \mathrm{mmHg}, \mathrm{paCO}_{2} 30 \mathrm{mmHg}, \mathrm{pH} 7.48\right.$, $\mathrm{paO}_{2} / \mathrm{FiO}_{2}$ ratio 171). Chest X-ray and CT of the thorax (Figure 2) revealed an opacity in the medio-basal right lung zone. The patient was treated with broadspectrum empirical antibiotics (piperacillin + tazobactam $4.5 \mathrm{~g} / 8 \mathrm{~h}$ plus levofloxacin $500 \mathrm{mg} / 12 \mathrm{~h}$ ). Non-invasive ventilation pressure support (PS) mode was implemented by setting PS $10 \mathrm{cmH}_{2} 0$, positive end expiratory pressure (PEEP) $8 \mathrm{cmH}_{2} \mathrm{O}$ and $\mathrm{FiO}_{2}$ $30 \%$. The ABG performed after 1 hour showed: $\mathrm{paO}_{2}$ 74, $\mathrm{paCO}_{2}$ 35, $\mathrm{pH} 7.39, \mathrm{paO}_{2} / \mathrm{FiO}_{2}$ 246. A bronchoaspirate and bronchoalveolar lavage yielded: multi-drug resistant Pseudomonas aeruginosa, Staphylococcus aureus, Streptococcus agalactiae and Candida albicans. The patient changed antibiotic therapy: tigecycline $50 \mathrm{mg} / 12 \mathrm{~h}$, colistimethate $300 \mathrm{mg}$ per day, fluconazole $400 \mathrm{mg}$ per day. Five days later clinical picture improved: leukocytes $8.30 \times 10^{9} / \mathrm{L}$, neutrophils $66 \%$, lymphocytes $20 \%$, C-reactive protein $3.2 \mathrm{mg} / \mathrm{dL}$, creatinine $0.69 \mathrm{mg} / \mathrm{dL}$. ABG: $\mathrm{paO}_{2} 68$, $\mathrm{paCO}_{2} 38, \mathrm{pH} 7.44, \mathrm{paO}_{2} / \mathrm{FiO}_{2} 283$ on $\mathrm{FiO}_{2} 24 \%$. NIV was suspended and patient continued oxygen therapy. Ten days later she was transferred to Respiratory Diseases Unit and discharged five days later.

\section{Case \#3}

A 71-year-old patient who recently underwent a surgical intervention because of lung cancer and adjuvant chemotherapy was admitted to ED complaining fever $\left(38.5^{\circ} \mathrm{C}\right)$, purulent expectoration and dyspnea and transferred to the Respiratory Sub-ICU. Clinical examination at admission to Respiratory Sub-ICU showed: respiratory rate 30 cardiac frequency 112 beats m' arterial pressure 100/50 mmHg. ABG in air

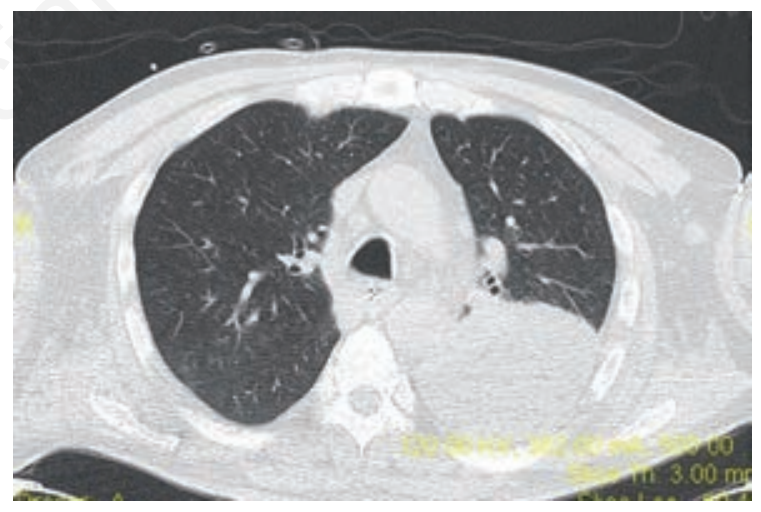

Figure 1. Computed tomography of the thorax. Opacity in the lower left pulmonary lobe.

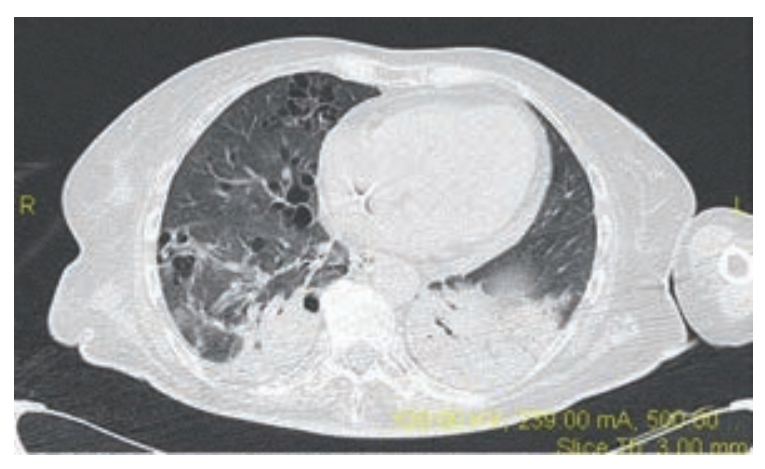

Figure 2. Computed tomography of the thorax. Opacity in the medio-basal right lung zone. 
room showed severe respiratory failure: $\mathrm{PaO}_{2} 39$, $\mathrm{paCO}_{2} 29, \mathrm{pH}$ 7.48, $\mathrm{paO}_{2} / \mathrm{FiO}_{2}$ 185. The non-invasive ventilation was started PS $12 \mathrm{cmH}_{2} 0$, PEEP $7 \mathrm{cmH}_{2} 0$, $\mathrm{FiO}_{2} 35 \%$. Chest X-ray and $\mathrm{CT}$ showed an opacity involving the upper right lobe with a wide excavation, and a small opacity at lower right lobe level (Figure 3). Laboratory findings showed: leukocytes $10.7 \times 10^{9} / \mathrm{L}$, neutrophils $95.4 \%$, lymphocytes $1.9 \%$, C-reactive protein $25.85 \mathrm{mg} / \mathrm{dL}$, pro-calcitonin $1.6 \mathrm{mg} / \mathrm{mL}$, fibrinogen $857 \mathrm{mg} / \mathrm{dL}$ (n.v. 180-450 mg/dL). The patient was treated initially with empirical antibiotic therapy: ceftriaxone $2 \mathrm{~g}$ day and levofloxacin $500 \mathrm{mg}$ every $12 \mathrm{~h}$. Blood culture, urinary antigen and sputum sample taken at admission were negative. Culture of bronchoalveolar lavage was positive for $S$. aureus methicillin-resistant, Enterococcus amnigenus and Enterococcus species. The three bacteria were sensitive to tigecycline, which was started $(50 \mathrm{mg} / 12 \mathrm{~h})$. Seven days later the patient's condition had improved and NIV was stopped. ABG showed: $\mathrm{paO}_{2} 78, \mathrm{paCO}_{2} 39$, $\mathrm{pH} 7.42, \mathrm{paO}_{2} / \mathrm{FiO}_{2} 312$ in $\mathrm{O}_{2} 25 \%$. Laboratory findings were: leukocytes $8.2 \times 10^{9} / \mathrm{L}$, neutrophils $81 \%$, lymphocytes $12 \%$, and C-reactive protein $0.85 \mathrm{mg} / \mathrm{dL}$. After fifteen days, the patient was discharged and twenty-seven day the chest X-ray findings cleared out.

\section{Discussion}

The role of mixed pneumonia in CAP has been described in recent years and demonstrated that has a different inflammatory pattern compared to bacterial or viral CAP. ${ }^{8}$ In a study conducted by Gutierrez et al. ${ }^{12}$ on 493 adult patients with CAP, polymicrobial infection was found in $5.7 \%$ of patients with microbiologically confirmed diagnosis. Polymicrobial infections were seen across all age groups and in patients treated both in hospital and in outpatient clinic. The most common polymicrobial infections were $S$. pneumoniae

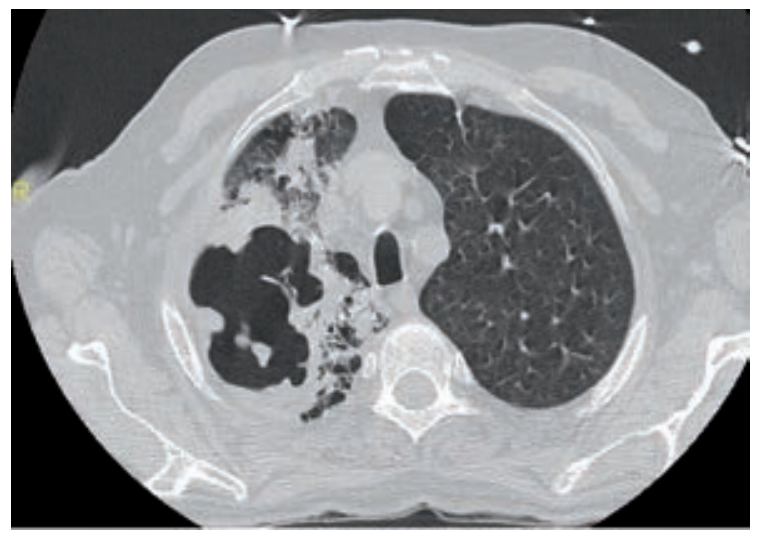

Figure 3. Computed tomography of the thorax. Opacity involving the upper right lobe with a wide excavation. with L. pneumophila and $S$. pneumoniae and Pseudomonas spp. Patients with polymicrobial infections are more likely to have underlying medical conditions and have more severe outcome. ${ }^{13,14} S$. pneumoniae was the most frequent co-pathogen in polymicrobial infections as previously reported..$^{15,16}$ Our case series report the most frequent causative organisms in hospitalized patients: ${ }^{17}$ it is not clear if the severity of the clinical picture is due to polymicrobial etiology or to causative organism in itself (e.g., $L$. pneumophila). ${ }^{18}$ Undoubtedly bacterial respiratory infection is often preceded by a viral infection which favors the secondary bacterial infection caused by a pathogen colonizing the respiratory mucosa. When a viral respiratory infection occurs, this destroys the respiratory epithelium, thus increases the adhesion of bacteria to the mucosa. ${ }^{13}$ The same can happen for atypical bacteria. Mycoses and in particular C. albicans, increases the virulence of $P$. aeruginosa and allows $S$. aureus to evade phagocytosis. ${ }^{13}$ For clinicians, it is very important: combined-empirical antimicrobial therapy may reduce mortality: ${ }^{18}$ International Guidelines have incorporated the idea that CAP could be due to polymicrobial agents in all patients. ${ }^{10,15-17}$ Rapid detection of Influenza may allow physician to use neuraminidase inhibitors effectively within 36 to $48 \mathrm{~h}$ from symptoms onset as well as rapid detection of $L$. pneumophila or S. pneumoniae via urinary test. ${ }^{18}$ The role of NIV is still under debate for patients with severe respiratory failure due to community acquired pneumonia because of lack of controlled clinical trials and its efficacy is less evident in decreasing the needs of intubation than in other diseases such as chronic obstructive pulmonary disease or cardiogenic pulmonary edema. ${ }^{19-21}$ Moreover, no study has investigated the difference between continuous PAP and BiPAP or pressure support ventilation (PSV) in severe respiratory failure due to pneumonia. ${ }^{11,19,21,22}$ Regarding the interfaces used to administering NIV in patients with hypoxemic acute respiratory failure some studies compared the helmet to facial mask: ${ }^{23,24}$ although the helmet group had a higher increase in oxygenation the total duration of NIV as well as the intubation rate and hospital mortality were similar in both groups. The mask group showed a higher intolerance to NIV. ${ }^{23}$ PSV administered via facial mask reduces work of breathing more significantly than helmet. The latter requires a higher pressurization to give the same level of PS. ${ }^{23,24}$ Thus, the use of helmet is suggested in cases in which NIV is used for long periods in order to avoid facial lesions and mask intolerance. ${ }^{23}$ However, in most patients, the best strategy is inter-change between different interfaces during the treatment. ${ }^{23,24}$ Our case series shows that in severe respiratory failure due to severe CAP the use of NIV is useful to avoid the needs of intubation. 


\section{Conclusions}

This case series suggests that polymicrobial CAP is often associated with more severe disease in adult patients. Rapid detection of all involved pathogens is paramount for a correct antimicrobial therapy, which allows reducing intensive care stay or mechanical ventilation.

Few laboratory parameters may be useful to suspect a polymicrobial CAP.

Non-invasive ventilation should be considered in the management of severe respiratory failure due to polymicrobial CAP.

\section{References}

1. Chertow DS, Memoli MJ. Bacterial coinfection in influenza: a grand rounds review. JAMA 2013;309:275-82.

2. Morens DM, Taubenberger JK, Fauci AS. Predominant role of bacterial pneumonia as a cause of death in pandemic influenza: implications for pandemic influenza preparedness. J Infect Dis 2008;198:962-70.

3. Ferrer M, Di Francesco LF, Liapikou A, et al. Polymicrobial intensive care unit acquired pneumonia: prevalence, microbiology and outcome. Crit Care 2015;19:450.

4. Mandell LA, Wunderink RG, Anzueto A, et al. Infectious Diseases Society of America. American Thoracic Society Infectious Diseases Society of America/American Thoracic Society consensus guidelines on the management of community-acquired pneumonia in adults. Clin Infect Dis 2007;44:S27-72.

5. Mongardon N, Max A, Bouglé A, et al. Epidemiology and outcome of severe pneumococcal pneumonia admitted to intensive care unit: a multicenter study. Crit Care 2012;16:R155.

6. Joseph C, Togawa Y, Shindo N. Bacterial and viral infections associated with influenza. Influenza Other Respir Viruses 2013;7:24-35.

7. Naderi H, Sheybani F, Servghad M, et al. Etiological diagnosis of community-acquired pneumonia in adult patients: a prospective hospital-based study in Mashhad, Iran. Jundishapur J Microbiol 2015;29:e22780.

8. Bello S, Minchole E, Fandos S, et al. Inflammatory response in mixed viral-bacterial community-acquired pneumonia. BMC Pulm Med 2014;14:123.

9. Carrillo A, Gonzales-Diaz G, Ferrer M, et al. Non-invasive ventilation in community-acquired pneumonia and severe acute respiratory failure. Intensive Care Med 2012;38:458-66.
10. Antonelli M, Conti G, Moro ML, et al. Predictors of failure of noninvasive positive pressure ventilation in patients with acute hypoxemic respiratory failure:a multicenter study.Intensive Care Med 2001;27:1718-28.

11. Nicolini A, Piroddi IMG, Barlascini C, Senarega R. Predictors of non invasive ventilation failure in severe respiratory failure due to community acquired pneumonia. Tanaffos 2014;13:20-8.

12. Gutierrez F, Masia M, Rodriguez JC, et al. Communityacquired pneumonia of mixed etiology: prevalence, clinical characteristics, and outcome. Rur J Clin Microbiol Infect Dis 2005;24:377-83.

13. Cilloniz C, Civljak R, Nicolini A, Torres A. Polymicrobial community acquired pneumonia: a new entity. Respirology 2016;21:65-75.

14. Ishiguro T, Takananagi N, Yamaguchi S, et al. Etiology and factors contributing to the severity and mortality of community-acquired pneumonia. Intern Med 2013;52: 317-24.

15. Cilloniz C, Ewig S, Polverino E, et al. Microbial aetiology of community-acquired pneumonia and its relation to severity. Thorax 2011;66:340-6.

16. Cilloniz C, Ewig S, Ferrer M, et al. Community-acquired polymicrobial pneumonia in the intensive care unit: aetiology and prognosis. Crit Care 2011;15:R209.

17. Rello J, Gattarello S, Souto J, et al. Community-acquired Legionella pneumonia in the intensive care unit: impact on survival of combined antibiotic therapy. Med Intens 2013;37:320-6.

18. Waterer GW, Rello J, Wunderlink RG. Management of community-acquired pneumonia. Concise clinical review. Am J Resp Crit care Med 2011;183:157-64.

19. Ferrer M, Cosentini R, Nava S. The use of non-invasive ventilation during acute respiratory failure due to pneumonia. Eur J Intern Med 2012;23:420-8.

20. DePascale G, Bello G, Tumbarello M, Antonelli M. Severe pneumonia in intensive care: cause, diagnosis, treatment and management: a review of the literature. Curr Opin Pulm Med 2012;18:213-21.

21. Ferrer M, Torres A. Non invasive ventilation for acute respiratory failure. Curr Opin Crit Care 2015;21:1-6.

22. Crimi C, Noto A, Princi P, Nava S. Survey of non-invasive ventilation in acute respiratory failure practices: a snapshot of Italian practice. Minerv Anestesiol 2011;77:971-8.

23. Esquinas AM, Papadakos PJ, Carron M, et al. Clinical review: helmet and non-invasive mechanical ventilation in critically ill patients. Crit Care 2013;17:223.

24. Chiumello D, Chevallard G, Gregoretti C. Non-invasive ventilation in postoperative patients: a systematic review. Intensive Care Med 2011;37:918-29. 